\title{
Factors Affecting the Performance of Small and Medium Enterprises in the Jua Kali Sector In Nakuru Town, Kenya
}

\author{
Anne Ngima Kinyua \\ Egerton University Nakuru Town Campus College Department of Accounting, Finance and Management \\ Science
}

\begin{abstract}
Interest in the role of small and medium-sized enterprises (SMEs) in the development process continues to be in the forefront of policy debates in developing countries. The role of finance, management skills, macro-environment factors and infrastructure have been viewed as a critical element for the performance of small and medium-sized enterprises. Therefore, this study sought to evaluate the factors affecting the performance of SMEs in the Jua Kali sector in Nakuru town. The study adopted a survey research design and employed a stratified random simple sampling. Primary data was collected from 262 study respondents using structured questionnaires.The data was analyzed descriptively and inferentially and presented through figures, tables and percentages. The findings indicate that; that access to finance had the potential to positively affect performance of SMEs; management skills were found to positively and significantly affect performance of SMEs; macro environment factors were found to significantly affect performance and Infrastructure did not significantly affect performance of SMEs in the study area. The study results also indicated that as number of years in operations increased the performance increased. The study recommends that banks should improve access to finance through offering $f$ better lending terms and conditions and collateral requirements; focus on acquiring appropriate management skills such as financial, marketing and entrepreneurial skills and effectively strengthen the macro environment in order to increase their performance.
\end{abstract}

Key words: Small and medium-sized enterprises, Performance,Jua kali sector

\section{Background of Study}

\section{Introduction}

The Informal sector is increasingly viewed as an important engine for employment creation and economic growth. This has been necessitated by the increasing awareness within the government that large projects in the industrial sector are less likely to generate the requisite employment opportunities, given the high capital-intensity of output in the sector

The role of finance has been viewed as a critical element for the performance of small and mediumsized enterprises. Previous studies have highlighted the limited access to financial resources available to smaller enterprises compared to larger organizations and the consequences for their performance and development (Levy, 1993). Typically, smaller enterprises face higher transactions costs than larger enterprises in obtaining credit (Saito and Villanueva, 1981). Insufficient funding has been made available to finance working capital (Peel and Wilson, 1996). Poor management and accounting practices have hampered the ability of smaller enterprises to raise finance. Information asymmetries associated with lending to small scale borrowers have restricted the flow of finance to smaller enterprises. In spite of these claims however, some studies show a large number of small enterprises fail because of non-financial reasons (Liedholm, MacPherson and Chuta, 1994). Study by Tushabonwe-Kazooba, (2006) revealed that poor record keeping and lack of basic business management experience and skills are major contributors to failure of small business. Researchers have also identified lack of access to external finance and weak capital base, inexperience in the field of business, particularly lack of technical knowledge plus inadequate managerial skills, lack of planning and lack of market research as causes of small business failure (Lussier 1996; Murphy, Shleifer and Vishny 1996; Van Stel and Storey 2004). The solution for solving problems of economic growth in developing countries often resides in the performance of small scale industries. It is expected that the gains to be derived from the establishment of small-scale industries will be translated into the generation of employment at a low investment cost. The focus of the study was on the factors which affect the performance of Small and Medium Enterprises (SMEs) in the Jua Kali sector of Kenya, a case of Nakuru Town.

The objectives of the study included; To examine the extent to which access to finance by SMEs in Jua Kali sector effects their performance; To examine the extent to which management skills have effect on performance of SMEs in Jua Kali sector; To examine the extent to which macro-environment factors have effects on the performance of SMEs in Jua Kali sector and to examine the extent to which infrastructure have affected the performance of SMEs in Jua Kali sector. 


\section{Research Hypotheses Of This Study Was;}

$\mathbf{H}_{01}$ : Accesses to finance does not significantly affect performance of SMEs in Jua Kali sector.

$\mathbf{H}_{02}$ : Management skills (Financial, Marketing and Entrepreneurial skills) do not significantly affect performance of SMEs in Jua Kali sector.

$\mathbf{H}_{\mathbf{0 3}}$ : Macro-environment factors do not significantly affect performance of SMEs in Jua Kali sector.

$\mathbf{H}_{04}$ : Infrastructure does not significantly affect performance of SMEs in Jua Kali sector.

\section{Literature Review}

The term "informal sector" was popularized by a 1972 study of Kenya, but Kenyans have another term for the sector: Juakali, literally "under the hot sun (ILO, 1972)." It is indicative of the severe conditions under which micro-entrepreneurs and their employees labour. This unstructured sector has emerged as a result of the incapacity of formal, regulated industries to absorb new entrants. The Jua Kali sector encompasses small scale entrepreneurs and workers who lack access to credit, property rights, training, and good working conditions. Originally restricted to artisans, the term has come to include a number of professions, including auto mechanics and market vendors.

Some studies estimate that informal businesses account for 35-50\% of GDP in many developing countries. Similarly, in Kenya, the informal sector is quite large, estimated at $34.3 \%$ and accounting for $77 \%$ of employment statistics .Over $60 \%$ of those working in the informal sector are the youth, aged between 18-35 years, 50\% being women (Ouma et al 2009).The First 1993 Small \& Medium Enterprises (SME) baseline survey revealed that there were approximately 910,000 SMEs employing up to 2 million people. The second SME baseline survey (1995), estimated the size of the SME sector at 708,000 enterprises employing up to 1.2 million people. Compared to the other sectors of the economy, the contribution of the SME sector to the country's Gross Domestic Product (GDP) increased from 13.8\% in1993 to over 18\% in 1999, (Sessional Paper No. 2 of 2005). Currently, it is estimated that the contribution to the GDP by this sector stands at over $25 \%$ (Economic Survey, 2012).

In Kenya, the Jua Kali as an informal sector, was traditionally run in the form of small industries in a few African homes which mainly dealt with blacksmithing activities (Maundu 1992). The advent of the Asian community to Kenya at the turn of the last century, marked the gradual shift of 'home-based' Jua Kali activity to urbanised enterprises. Among the initial urban Jua Kali enterprises introduced were motor-mechanics, carpentry, masonry, tinsmithery and blacksmithery (Maundu 1992). With time, the indigenous Kenyans soon entered the market and gradually expanded the industry by producing a wide range of such items as jikos (braziers), cooking and frying pans, steel windows, tin lamps, motor spares and leather artefacts . Today the Jua Kali industry represents an enormous conglomeration of products in many towns and villages across the Republic of Kenya.

Despite the critical role played by the small enterprise sector, it is faced with numerous challenges and constraints that include unfavorable policy, access to financial services and markets, inadequate business knowhow and linkages with large enterprises, gender inequality, job quality deficits, limited access to information, impact of HIV/AIDS pandemic, unsatisfactory occupational health and safety standards. These constraints have not been well-addressed resulting in a weak base for industrial take-off and sustainable development. Nevertheless, the field of small businesses still remains attractive because the creative enterprising individual likes to be independent and be in control of action and issuing instructions (Sessional Paper No. 2; 2005).

Access to finance has been identified as a dominant constraint facing SMEs (Lader, 1996). A World Bank study found that about $90 \%$ of small enterprises surveyed stated that credit was a major constraint to new investment (Parker et al., 1995). Levy (1993) also found that, there is limited access to financial resources available to smaller enterprises compared to larger organizations and the consequences for their low growth and development. This stems from the fact that SMEs have limited access to capital markets partly due to the perception of higher risk, informational barriers, and the higher costs of intermediation for smaller firms. (Biekpe, 2004)). Previous studies have identified a growing gap in the financial support offered to Ghanaian SMEs. The high interest rates, collateral requirements and the cumbersome processes have often been mentioned as the main impediments to SMEs' access to bank loans in Ghana (see Sowa et al., 1992; Aryeetey et al., 1994; Bigsten et al., 2000; Buatsi, 2002).

A number of studies have found that there is a correlation between firm age and access to credit. Being in the business for many years suggests that the firms are at least competitive on average. It can be argued that being an older firm means there is lower informational opacity. On the other hand, the new firms are not likely to meet the collateral requirements of the banks since they have not accumulated sufficient assets. Combined with the absence of information on their financial records, this makes it difficult to lenders to assess lending proposals submitted by new firms. Proceedings of ASBBS Volume 18 Number 1 ASBBS Annual Conference: Las Vegas 259 February 2011. The studies conducted in the past have found that the financing constraints are particularly severe in startup enterprises and relatively young firms (three years old or less).For example, 
Aryeetey et al (1994) conducted a survey of 133 firms, of which 76 had less than 10 workers, in various industries in Ghana in the early 1990s. They found that only 10 percent of startup firms in Ghana could obtain bank loans but medium size enterprises and older firms are provided with credit three times more often than their smaller counterparts.

The studies conducted by Ibrahim (1986), provide evidence that management skills are critical factors in both the failure and success of businesses (Lichtenstein \& Brush, 2001). They illustrate that accounting, cash flow, and marketing need management skills and lack of them is a major cause of failure. Weaknesses in these areas are found to impact on all other areas of the business. A lack of management skills and expertise is a major constraint hindering the progress of the SME sector in Kenya.

The macro-environment consists of stakeholder groups that a firm has regular dealings with. The way these relationships develop can affect the costs, quality and overall success of a business. Although the move towards economic liberalization proposed in the late 1980s and 1990s was aimed at reducing distortions in the economy, deregulation of markets has had adverse impact on SMEs (Sessional Paper No. 2, 2005). The effects include increased macro-economic instability characterized by high inflation rate, current account deficits and policy uncertainty. While the effects have been harmful to all private enterprises, the SMEs have been particularly hurt given their small size, and because they have fewer options to ride over instabilities.

For business owners, important regulations include state actions relating to the following nonexhaustive list; contract enforcement, property rights, including intellectual property, corporate governance, taxation and financial reporting, employment and health and safety, trading standards and consumer rights, environmental protection, premises and planning rules, data protection, transport. Environmental regulations concerning the storage and use of hazardous substance are likely to have a greater impact on certain sectors than others, for example, agriculture, manufacturing and transport and communications businesses (Carter et al., 2004).

In infrastructure planning, Ombura (1997) points that infrastructure networks are useful instruments within network economies. Infrastructure and related services help to make things happen, it feeds and it is fed by trade, it fuels foreign direct investment, it backs up the creation and sustainability of industrial clusters, it cuts costs and raises competitiveness. A spatial planning approach ensures the most efficient use of land by balancing competing demands within the context of sustainable development (Rozee, 2003). It becomes an ongoing, enduring process of managing change by a range of actors, in the interests of sustainable development (Tewdwr, 2004). This makes efforts to promote industrial development extremely urgent and rural focused.

Entrepreneurial and small and medium-sized enterprises (SMEs) firm performance is a complex, multifaceted construct that should be examined with an eye toward its complexity. Yonggui et. al. (2002) examined a set of internal and external factors/variables that may be critical to distinguish high-growth SMEs from those of poor performance. The study based on the relationship between factors and determinants concerning entrepreneur/top management team, firm characteristics, organizational strategies and external environment, and poor performance and high-growth performance in SMEs in China. Van de Ven (1993) emphasized that the process of entrepreneurship is not limited to the for profit sector; numerous entrepreneurial factors in the public and not-for-profit sectors play crucial roles. It motivates one to examine the different roles played by these factors, and how their joint contributions interact to develop and commercialize a new technology. This in turn makes it possible to understand how the risk, time, and cost to an individual entrepreneur are significantly influenced by developments in the overall infrastructure for entrepreneurship.

The small and micro enterprises (SMEs) play an important role in the Kenyan Economy. According to the Economic Survey (2006), the sector contributed over 50 percent of new jobs created in the year 2005. Despite their significance, past statistics indicate that three out of five businesses fail within the first few months of operation (Kenya National Bureau of Statistics, 2007). According to Amyx (2005), one of the most significant challenges is the negative perception towards SMEs. Potential clients perceive small businesses as lacking the ability to provide quality services and are unable to satisfy more than one critical project simultaneously. Often larger companies are selected and given business for their clout in the industry and name recognition alone.

As with many developing countries, there is limited research and scholarly studies about the SME in Jua Kali sector in Kenya. The 1999 National Baseline Survey conducted by Central Bureau of Statistics, ICEG and K-Rep Holdings provides the most recent comprehensive picture of SMEs in Kenya. Mead (1998) observes that the health of the economy as a whole has a strong relationship with the health and nature of micro and small enterprise sector. When the state of the macro economy is less favorable, the opportunities for profitable employment expansion in SMEs are limited. This is true especially for those SMEs that have linkages to larger enterprises and the economy at large. Given this scenario, an understanding of the dynamics of SMEs is necessary not only for the development of support programmes for SMEs, but also for the growth of the economy as a whole. Given the importance of small businesses to the Kenyan economy and the exposure to 
risks owing to their location, there is need to conduct an empirical enquiry to investigate into the factors affecting the performance of SMEs in the Jua Kali sector in Nakuru Town, Kenya.

\section{Methodology Of The Study}

The study adopted survey research design to achieve the objectives. The study employed stratified random simple sampling. The population was segregated into several mutually exclusive subpopulations or strata herein referred to as business categories as shown in appendixes. There were 759 SMEs in the Jua Kali sector in Nakuru Town as per Nakuru municipal council licensing department (See Appendix 1).

The research applied proportionate stratification that is based on the stratum's share of the total population to come up with the sample in each stratum. The actual businesses interviewed were arrived at by using simple random procedures to draw the sample from each stratum. The sample size was determined by the following formula (Yamane, 1967).

$$
n=\frac{N}{1+N(e)^{2}}
$$

Where

n - $\quad$ is the sample size,

$\mathbf{N}$ - $\quad$ is the population size, and

e - $\quad$ is the level of precision.

In this case $\mathrm{N}$ is $759, \pm 5 \%$ Precision Levels where Confidence Level was $95 \%$ and $\mathrm{P}=.5$

Hence, the sample size of the study was 262.

Out of 262 respondents, $16.41 \%$ were carpentry, $26.34 \%$ of businesses were mechanics, $17.56 \%$ were scrap metals while $39.69 \%$ were welders and fabricators. The respondents were composed of $77.9 \%$ of owners, $16 \%$ were supervisors/attendants and $6.1 \%$ of the respondents were partners.

The study employed a structured questionnaire to gather information from the study respondents. A likert type scale was used to collect information on evaluation of factors affecting performance of SMEs. Descriptive statistics and inferential statistical techniques were used to analyze the data. This study applied Pearson moment correlation to determine the strength and direction of association between factors affecting performance of SMS. Regression analysis was used to test the overall factors affecting performance of SMEs on performance of Jua Kali Sector. The regression is based on the linear equation model expressed as: $Y=b_{0}+$ $b_{1} x_{1}+b_{2} x_{2}+b_{3} x_{3}+b_{4} x_{4}+b_{5} x_{5}$. Where $Y=$ dependent variable (Performance Jua Kali Sector)

$\mathrm{b}_{0}=$ constant $; \mathrm{b}_{1}, \mathrm{~b}_{2}, \mathrm{~b}_{3}, \mathrm{~b}_{4}, \mathrm{~b}_{5}=$ corrélation coefficient and $\mathrm{x}_{1}, \mathrm{x}_{2}, \mathrm{x}_{3}, \mathrm{x}_{4}, \mathrm{x}_{5}=$ independent variables (Access to finance, Management Skills, Macro Environment and Infrastructure). The data was analyzed with the help of the Statistical Package for Social Sciences computer software.

\section{Results}

Survey results showed that $43.5 \%$ of the SMEs had been in operation for $6-10$ years, $37 \%$ had operated for $11-15$ years, $14.5 \%$ had operated for 1-5 years while 5\% had operated for 16-20 years. Table 1: Age of business in years.

\begin{tabular}{|l|c|c|}
\hline Age Group & Frequency & Percent \\
\hline $1-5 \mathrm{yrs}$ & 38 & 14.5 \\
\hline 6-10yrs & 114 & 43.5 \\
\hline 11-15yrs & 97 & 37.0 \\
\hline 16-20yrs & 13 & 5.0 \\
\hline Total & $\mathbf{2 6 2}$ & $\mathbf{1 0 0 . 0}$ \\
\hline
\end{tabular}

Effect of Lending Terms and Conditions on Performance. 62.6\% of the respondents reported that to a great extent lack of financial records made it difficult for SMEs to access lending proposals, $35.5 \%$ reported to some extent while $1.9 \%$ reported not at all. $86.6 \%$ of the respondents reported that most financial institutions were reluctant to provide long-term credit to SMEs while $13.4 \%$ reported to some extent. $63.3 \%$ of the respondents reported that high interest rates, premium cost and other loan processing cost made SMEs unable to obtain funds from banks, whereas $36.7 \%$ reported to some extent. 
Table 2: Effect of Lending Terms and Conditions on Performance

\begin{tabular}{|l|l|l|l|l|l|l|}
\hline Statement & \multicolumn{9}{|c|}{ Percentage Response (\%) } & Mean \\
\hline & $\begin{array}{l}\text { Not at } \\
\text { all }\end{array}$ & $\begin{array}{l}\text { To a } \\
\text { low } \\
\text { Extent }\end{array}$ & $\begin{array}{l}\text { To } \\
\text { some } \\
\text { extent }\end{array}$ & $\begin{array}{l}\text { To } \\
\text { greater } \\
\text { extent }\end{array}$ & $\begin{array}{l}\text { To great extent } \\
\text { grery }\end{array}$ & \\
\hline $\begin{array}{l}\text { Lack of financial records makes it } \\
\text { difficult to access finance }\end{array}$ & 1.9 & 5.0 & 30.5 & 60.3 & 2.3 & 3.561 \\
\hline $\begin{array}{l}\text { Most financial institutions are } \\
\text { reluctant to provide long-term credit } \\
\text { to SMEs. }\end{array}$ & 0.0 & 1.1 & 12.3 & 72.5 & 14.1 & \\
\hline $\begin{array}{l}\text { High interest rates, premium cost and } \\
\text { other loan processing cost makes } \\
\text { SMEs unable to obtain funds from } \\
\text { banks. }\end{array}$ & 0.0 & 0.8 & 35.9 & 58.3 & 5.0 & \\
\hline
\end{tabular}

Source: Research Data (2013)

Collateral Requirements and Performance of SMEs. The findings revealed that, $44.1 \%$ of the respondents reported that firms with intangible assets could only borrow less, $35.1 \%$ to some extent while $0.8 \%$ not at all. $59.5 \%$ of the respondents reported that SMEs could not afford the required collateral, $39.7 \%$ reported to some extent while $0.8 \%$ reported not at all. $67.2 \%$ of the respondents reported that SMEs lacked accumulation of sufficient assets, $30.1 \%$ reported to some extent while $2.7 \%$ not at all.

Table 3 Effect of Collateral Requirements on Performance of SME

\begin{tabular}{|c|c|c|c|c|c|c|}
\hline \multirow[t]{2}{*}{ Statement } & \multicolumn{5}{|c|}{ Percentage Response (\%) } & \multirow[t]{2}{*}{ Mean } \\
\hline & $\begin{array}{l}\text { Not at } \\
\text { all }\end{array}$ & $\begin{array}{l}\text { To a low } \\
\text { Extent }\end{array}$ & $\begin{array}{ll}\text { To } & \text { some } \\
\text { extent } & \end{array}$ & $\begin{array}{l}\text { To a greater } \\
\text { extent }\end{array}$ & $\begin{array}{l}\text { To a very great } \\
\text { extent }\end{array}$ & \\
\hline $\begin{array}{l}\text { Firms with intangible } \\
\text { assets can only borrow } \\
\text { less. }\end{array}$ & 0.8 & 3.8 & 31.3 & 39.9 & 4.2 & 3.629 \\
\hline $\begin{array}{l}\text { SMEs cannot afford } \\
\text { the required collateral. }\end{array}$ & 0.8 & 1.5 & 38.2 & 53.8 & 5.7 & 3.622 \\
\hline
\end{tabular}

Source: Research Data (2013)

Number of Years in Operation and Performance. Study findings revealed that $58.5 \%$ reported that to a great extent SMEs which had operated for long number of years developed good business track record and reputation, $36.3 \%$ reported to some extent while $7.2 \%$ reported not at all. $55.7 \%$ of the respondents reported that to a great extent SMEs which have operated for long number of years had developed accounting systems and established legal identity, $40.1 \%$ reported to some extent while $4.2 \%$ reported not at all. $64.9 \%$ of the respondents reported that to great extent old firms had information required by the lenders to evaluate and process applications, $29.7 \%$ reported to some extent while $5.4 \%$ reported not at all.

Table 4 Effect of the Number of years in Operation on Performance Source: Research Data (2013)

\begin{tabular}{|l|l|l|l|l|l|l|}
\hline Statement & \multicolumn{3}{|l|}{ Percentage Response (\%) } & \multicolumn{2}{|c|}{ Mean } \\
\hline & $\begin{array}{l}\text { Not at } \\
\text { all }\end{array}$ & $\begin{array}{l}\text { To a low } \\
\text { Extent }\end{array}$ & $\begin{array}{l}\text { To some } \\
\text { extent }\end{array}$ & $\begin{array}{l}\text { To } \\
\text { greater } \\
\text { extent }\end{array}$ & $\begin{array}{l}\text { great } \\
\text { extent }\end{array}$ \\
\hline $\begin{array}{l}\text { SMEs which have operated for long number } \\
\text { of years develop good business track record } \\
\text { and reputation. }\end{array}$ & 7.2 & 4.2 & 32.1 & 53.1 & 3.4 \\
\hline $\begin{array}{l}\text { SMEs which have operated for long number } \\
\text { of years have developed accounting systems } \\
\text { and establishes legal identity }\end{array}$ & 4.6 & 3.8 & 36.3 & 53.8 & 1.9 \\
\hline $\begin{array}{l}\text { Old firms have information required by the } \\
\text { lenders to evaluate and process applications. }\end{array}$ & 5.4 & 5.3 & 24.4 & 62.6 & 3.438 \\
\hline
\end{tabular}

Financial Management and Performance of SMEs. According to the findings, $4.2 \%$ of the respondents reported to a great extent SMEs had well maintained financial records, 37.8\% reported to some extent while $58 \%$ reported not at all. $2.6 \%$ of the respondents reported that to a great extent cash was well managed , $71.4 \%$ reported to some extent while $26 \%$ reported not at all. In addition, only $3.1 \%$ of the respondents reported that to 
a great extent SMEs differentiated on capital and income, 39.4\% reported to some extent while $57.6 \%$ reported not at all.

Table 5 Effect of Financial Management on Performance

\begin{tabular}{|l|l|l|l|l|l|l|}
\hline Statement & \multicolumn{5}{|c|}{ Percentage Response (\%) } & Mean \\
\hline & Not at all & To a low Extent & To some extent & To a greater extent & $\begin{array}{l}\text { To a very } \\
\text { great extent }\end{array}$ & \\
\hline $\begin{array}{l}\text { SMEs have well maintained } \\
\text { financial records. }\end{array}$ & 58.0 & 5.7 & 32.1 & 3.8 & 0.4 & 1.828 \\
\hline $\begin{array}{l}\text { Cash is well managed and no } \\
\text { withdraws are made by the } \\
\text { owners without consideration } \\
\text { of net income generated. }\end{array}$ & 26.0 & 12.6 & 58.8 & 2.6 & 0.0 & 2.381 \\
\hline $\begin{array}{l}\text { SMEs differentiate on capital } \\
\text { and income. }\end{array}$ & 57.6 & 9.2 & & & & \\
\hline
\end{tabular}

Marketing Management and Performance of SMEs. This study revealed that $31.6 \%$ of the respondents generally reported that to some extent the marketing plan was well prepared while $68.4 \%$ reported not at all. This study also revealed that only $1.5 \%$ of the respondents generally reported that to a great extent SMEs were capable of satisfying customer needs while meeting stakeholders expectations, $77.5 \%$ reported to some extent while $21 \%$ reported not at all. In addition only $3.1 \%$ of the respondents generally reported that to a great extent SMEs were capable of creating a competitive edge, $68.3 \%$ reported to some extent while $28.6 \%$ reported not at all.

The study findings revealed that $1.1 \%$ of the respondents generally reported that to a great extent SMEs were capable of identifying target markets, 55.3\% reported to some extent while $43.5 \%$ reported not at all. Finally, $1.9 \%$ of the respondents generally agreed that reported that to a great extent SMEs were capable of identifying promotional activities, $32.1 \%$ reported to some extent while $66 \%$ reported not at all.

Table 6 Effect of Marketing Management on Performance of SMEs

\begin{tabular}{|l|l|l|l|l|l|}
\hline Statement & \multicolumn{5}{|c|}{ Percentage Response (\%) } \\
\hline & $\begin{array}{l}\text { Not at } \\
\text { all }\end{array}$ & $\begin{array}{l}\text { To a low } \\
\text { Extent }\end{array}$ & $\begin{array}{l}\text { To some } \\
\text { extent }\end{array}$ & $\begin{array}{l}\text { To a greater } \\
\text { extent }\end{array}$ & $\begin{array}{l}\text { To a } \\
\text { great extent }\end{array}$ \\
\hline Marketing plan is well prepared. & 68.4 & 16.0 & 15.6 & 0.0 & 0.0 \\
\hline $\begin{array}{l}\text { SMEs are capable of satisfying customer needs } \\
\text { while meeting stakeholders expectations. }\end{array}$ & 21.0 & 17.6 & 59.9 & 1.5 & 0.0 \\
\hline Its capable to create a competitive edge. & 28.6 & 16.4 & 51.9 & 3.1 & 0.0 \\
\hline Its capable of identifying target markets. & 43.5 & 18.7 & 36.6 & 1.1 & 0.0 \\
\hline Its capable to identify promotional activities. & 66.0 & 17.2 & 14.9 & 1.9 & 0.0 \\
\hline
\end{tabular}

Source: Research Data (2013)

Entrepreneurial Skills and Performance of SMEs. According to study findings, $12.4 \%$ of the respondents reported that to a great extent they had undertaken trainings on business skills, $26.4 \%$ reported to some extent while $61.2 \%$ reported not at all. The study findings indicated that

$5 \%$ of the respondents reported that to a great extent they had been trained on drafting business plans, $21 \%$ reported to some extent while $74 \%$ reported not at all. $1.5 \%$ of the respondents reported that to a great extent they had specialized training on productivity, environmental awareness, 10\% reported to some extent while $88.5 \%$ reported not at all. Finally, study findings revealed that $9.2 \%$ of the respondents reported that to a great extent they had training on establishing net works, partnerships and joint ventures, $12.2 \%$ reported to some extent while $78.6 \%$ reported not at all

Table 7 Effect of Entrepreneurial Skills on Performance

\begin{tabular}{|l|l|l|l|l|l|}
\hline Statement & \multicolumn{5}{|c|}{ Percentage Response (\%) } \\
\hline & $\begin{array}{l}\text { Not at } \\
\text { all }\end{array}$ & $\begin{array}{l}\text { To a low } \\
\text { Extent }\end{array}$ & $\begin{array}{l}\text { To some } \\
\text { extent }\end{array}$ & $\begin{array}{l}\text { To } \\
\text { greater } \\
\text { extent }\end{array}$ & $\begin{array}{l}\text { To a very great } \\
\text { extent }\end{array}$ \\
\hline $\begin{array}{l}\text { Have been taking trainings on business } \\
\text { skills. }\end{array}$ & 61.2 & 3.1 & 23.3 & 12.4 & 0.0 \\
\hline $\begin{array}{l}\text { Have been trained on drafting business } \\
\text { plans. }\end{array}$ & 74.0 & 3.8 & 17.2 & 5.0 & 0.0 \\
\hline $\begin{array}{l}\text { Has specialized training on productivity, } \\
\text { environmental awareness. }\end{array}$ & 88.5 & 3.1 & 6.9 & 1.5 & 0.0 \\
\hline $\begin{array}{l}\text { Has training on establishing net works, } \\
\text { partnerships and joint ventures. }\end{array}$ & 78.6 & 5.7 & 6.5 & 9.2 & 0.0 \\
\hline
\end{tabular}

Source: Research Data (2013) 
Regulations and Policy Issues and Performance of SMEs. Study findings revealed that $2.3 \%$ of the respondents generally reported that to a great extent the firm was required to adhere to property rights, $19.4 \%$ reported to some extent while $78.3 \%$ reported not at all. In addition, study findings revealed that $48.1 \%$ of the respondents generally reported that to a great extent the firm was required to adhere taxation and financial reporting, $28.6 \%$ reported to some extent while $23.3 \%$ reported not at all.

In addition, $17.1 \%$ of the respondents generally reported that to a great extent the firm was required to adhere to employment, health and safety standards, $30.5 \%$ reported to some extent while $53.4 \%$ reported not at all. Further, $43.1 \%$ of the respondents generally reported that to a great extent the firm was required to adhere to environmental protection, $34.3 \%$ reported to some extent while $22.3 \%$ reported not at all. Also, $3.1 \%$ of the respondents generally reported that to a great extent the firm was required to adhere to premises and planning rules, $16 \%$ reported to some extent while $80.9 \%$ reported not at all. Finally, $2.2 \%$ of the respondents generally reported that the firm was required to adhere to trading standards and customer rights, $14.2 \%$ reported to some extent while $88.6 \%$ reported not at all.

Table 8 Effect of Regulations and Policy Issues on Performance

\begin{tabular}{|c|c|c|c|c|c|c|}
\hline \multirow[t]{2}{*}{ Statement } & \multicolumn{5}{|c|}{ Percentage Response (\%) } & \multirow[t]{2}{*}{ Mean } \\
\hline & $\begin{array}{l}\text { Not at } \\
\text { all }\end{array}$ & $\begin{array}{l}\text { To a low } \\
\text { Extent }\end{array}$ & $\begin{array}{l}\text { To some } \\
\text { extent }\end{array}$ & $\begin{array}{l}\text { To a greater } \\
\text { extent }\end{array}$ & $\begin{array}{l}\text { To a very } \\
\text { great extent }\end{array}$ & \\
\hline $\begin{array}{l}\text { The firm is required to adhere to } \\
\text { Property rights }\end{array}$ & 78.3 & 3.4 & 16.0 & 2.3 & 0.0 & 1.423 \\
\hline $\begin{array}{l}\text { The firm is required to adhere } \\
\text { Taxation and financial reporting }\end{array}$ & 23.3 & 5.3 & 23.3 & 43.9 & 4.2 & 3.003 \\
\hline $\begin{array}{l}\text { The firm is required to adhere } \\
\text { Employment and health and } \\
\text { safety standards }\end{array}$ & 53.4 & 7.6 & 22.9 & 16.0 & 1.1 & 2.061 \\
\hline $\begin{array}{l}\text { The firm is required to adhere to } \\
\text { Environmental protection }\end{array}$ & 22.6 & 8.0 & 26.3 & 39.3 & 3.8 & 2.939 \\
\hline $\begin{array}{l}\text { The firm is required to adhere to } \\
\text { Premises and planning rules }\end{array}$ & 80.9 & 1.5 & 14.5 & 2.3 & 0.8 & 1.404 \\
\hline $\begin{array}{l}\text { The firm is required to adhere to } \\
\text { Trading standards and customer } \\
\text { rights }\end{array}$ & 88.6 & 5.0 & 9.2 & 1.1 & 1.1 & 1.313 \\
\hline
\end{tabular}

Source: Research Data (2013)

Suppliers and Performance of SMEs. This study revealed that $6.9 \%$ of the respondents generally reported that to a great extent the SMEs were capable of providing high quality raw materials at appropriate prices, $79.8 \%$ reported to some extent while $13.3 \%$ reported not at all. This study also revealed that $18.3 \%$ of the respondents generally reported that to a great extent the SMEs were capable of providing reliable volumes of raw materials, $70.2 \%$ reported to some extent while $11.5 \%$ reported not at all. Finally, $12.6 \%$ of the respondents generally reported that to a great extent the SMEs had flexibility to changing volumes, $74 \%$ reported to some extent while $13.4 \%$ reported not at all.

Table 9 Effect of Suppliers on Performance

\begin{tabular}{|l|l|l|l|l|l|l|}
\hline Statement & \multicolumn{5}{|c|}{ Percentage Response (\%) } & Mean \\
\hline & $\begin{array}{l}\text { Not at } \\
\text { all }\end{array}$ & $\begin{array}{l}\text { To a low } \\
\text { Extent }\end{array}$ & $\begin{array}{l}\text { To some } \\
\text { extent }\end{array}$ & $\begin{array}{l}\text { To a greater } \\
\text { extent }\end{array}$ & $\begin{array}{l}\text { To a very great } \\
\text { extent }\end{array}$ & 0.8 \\
\hline $\begin{array}{l}\text { Capable to provide high quality raw } \\
\text { materials at appropriate prices }\end{array}$ & 13.3 & 8.0 & 71.8 & 6.1 & 2.729 \\
\hline $\begin{array}{l}\text { Capable to provide reliable volumes of } \\
\text { raw materials }\end{array}$ & 11.5 & 6.5 & 63.7 & 18.3 & 0.0 \\
\hline Have flexibility to changing volumes & 13.4 & 7.6 & 66.4 & 12.6 & 0.0 \\
\hline
\end{tabular}

Source: Research Data (2013)

Distributors and Performance of SMEs. According to study findings, $1.1 \%$ of the respondents generally reported that to a great extent the SMEs availed adequate stores to stock firm's product, $31.7 \%$ reported to some extent while $67.2 \%$ reported not at all. Further, the study findings indicated that $1.9 \%$ of the respondents generally reported that to a great extent the SMEs adequately displayed firms products in their shelves, 34\% reported to some extent while $64.1 \%$ reported not at all. 
Table 10 Effect of Distributors on Performance

\begin{tabular}{|l|l|l|l|l|l|l|}
\hline Statement & \multicolumn{5}{|c|}{ Percentage Response (\%) } & Mean \\
\hline & $\begin{array}{l}\text { Not } \\
\text { at all }\end{array}$ & $\begin{array}{l}\text { To a low } \\
\text { Extent }\end{array}$ & $\begin{array}{l}\text { To } \\
\text { some } \\
\text { extent }\end{array}$ & $\begin{array}{l}\text { To } \\
\text { greater } \\
\text { extent }\end{array}$ & $\begin{array}{l}\text { To a very } \\
\text { great extent }\end{array}$ \\
\hline Avail adequate stores to stock firms product & 67.2 & 8.0 & 23.7 & 1.1 & 0.0 & 1.587 \\
\hline $\begin{array}{l}\text { Adequately displays firms products in their } \\
\text { shelves }\end{array}$ & 64.1 & 14.1 & 19.8 & 0.8 & 1.1 & 1.606 \\
\hline
\end{tabular}

Source: Research Data (2013)

Customers and Performance of SMEs. Study findings revealed that $9.9 \%$ of the respondents generally reported that to a great extent their needs were met effectively, $75.6 \%$ reported to some extent while $14.5 \%$ reported not at all. In addition, study findings revealed that $22.9 \%$ of the respondents generally reported that to a great extent there was good relation with customers through incentives, $69.9 \%$ reported to some extent while $8 \%$ reported not at all.

Table 11 Effect of Customers on Performance

\begin{tabular}{|l|l|l|l|l|l|}
\hline Statement & \multicolumn{5}{|c|}{ Percentage Response (\%) } \\
\hline & $\begin{array}{l}\text { Not at } \\
\text { all }\end{array}$ & $\begin{array}{l}\text { To a low } \\
\text { Extent }\end{array}$ & $\begin{array}{l}\text { To some } \\
\text { extent }\end{array}$ & $\begin{array}{l}\text { To greater } \\
\text { grtent } \\
\text { exten }\end{array}$ & $\begin{array}{l}\text { To a very great } \\
\text { extent }\end{array}$ \\
\hline Their needs are met effectively & 14.5 & 8.0 & 67.6 & 9.9 & 0.0 \\
\hline $\begin{array}{l}\text { There is good relation with } \\
\text { customers through incentives }\end{array}$ & 8.0 & 5.0 & 64.9 & 21.0 & 1.1 \\
\hline
\end{tabular}

Source: Research Data (2013)

Competitors and Performance of SMEs. $4.2 \%$ of the respondents generally reported that to a great extent the firm had a bigger market share than competitors, $30.5 \%$ reported to some extent while $65.3 \%$ reported not at all. Also, $8.1 \%$ of the respondents generally reported that to a great extent the firm was capable of offering excellent products than its competitors, 59.9\% reported to some extent while $32 \%$ reported not at all. Finally, 59.5\% of the respondents generally reported that to a great extent the firm offered favorable prices, $34.8 \%$ reported to some extent while $5.7 \%$ reported not at all.

Table 12 Effect of Competitors on Performance

\begin{tabular}{|l|l|l|l|l|l|l|}
\hline Statement & \multicolumn{5}{|c|}{ Percentage Response (\%) } & Mean \\
\hline & $\begin{array}{l}\text { Not at } \\
\text { all }\end{array}$ & $\begin{array}{l}\text { To a low } \\
\text { Extent }\end{array}$ & $\begin{array}{l}\text { To some } \\
\text { extent }\end{array}$ & $\begin{array}{l}\text { To } \\
\text { greater } \\
\text { extent }\end{array}$ & $\begin{array}{l}\text { To } \\
\text { very } \\
\text { great } \\
\text { extent }\end{array}$ \\
\hline $\begin{array}{l}\text { The firm has a bigger market share than } \\
\text { competitors }\end{array}$ & 65.3 & 9.5 & 21.0 & 3.4 & 0.8 \\
\hline $\begin{array}{l}\text { The firm is capable to offer excellent } \\
\text { products than its competitors }\end{array}$ & 32.0 & 9.9 & 50.0 & 7.3 & 0.8 & 2.347 \\
\hline \begin{tabular}{l} 
The firm offers favorable prices \\
\hline
\end{tabular} & 5.7 & 3.1 & 31.7 & 42.7 & 16.8 \\
\hline
\end{tabular}

Source: Research Data (2013)

Water and Performance of SMEs. $42.8 \%$ of the respondents generally reported that to a great extent there was adequate water, $55 \%$ reported to some extent while $2.2 \%$ reported not at all. This study also revealed that $46.2 \%$ of the respondents generally reported that to a great extent the cost of water was adequate to their sector, $49.2 \%$ reported to some extent while $17.3 \%$ reported not at all.

Table 13 Effect of Water on Performance

\begin{tabular}{|l|l|l|l|l|l|l|}
\hline Statement & \multicolumn{7}{|c|}{ Percentage Response (\%) } & Mean \\
\hline & $\begin{array}{l}\text { Not at } \\
\text { all }\end{array}$ & $\begin{array}{l}\text { To a low } \\
\text { Extent }\end{array}$ & $\begin{array}{l}\text { To } \\
\text { some } \\
\text { extent }\end{array}$ & $\begin{array}{l}\text { To extent } \\
\text { greater } \\
\text { exter }\end{array}$ & $\begin{array}{l}\text { To a very great } \\
\text { extent }\end{array}$ \\
\hline There is adequate water & 2.2 & 8.8 & 46.2 & 42.0 & 0.8 & 3.301 \\
\hline $\begin{array}{l}\text { The cost of water is adequate to } \\
\text { your sector }\end{array}$ & 4.6 & 4.2 & 45.0 & 46.2 & 0.0 & 3.328 \\
\hline
\end{tabular}

Source: Research Data (2013) 
Electricity and Performance of SMEs. According to study findings, 39.3\% of the respondents generally reported that to a great extent there was adequate electricity, $46.8 \%$ reported to some extent while $14.9 \%$ reported not at all. Further, the study findings indicated that $37.7 \%$ of the respondents generally reported that to a great extent the cost of electricity was affordable to your sector, $45 \%$ reported to some extent while $17.3 \%$ reported not at all.

Table 14 Effect of Electricity on Performance of SMEs

\begin{tabular}{|l|l|l|l|l|l|l|}
\hline Statement & \multicolumn{5}{|c|}{ Percentage Response (\%) } & Mean \\
\hline & Not at all & $\begin{array}{l}\text { To a low } \\
\text { Extent }\end{array}$ & $\begin{array}{l}\text { To some } \\
\text { extent }\end{array}$ & $\begin{array}{l}\text { To } \\
\text { greater } \\
\text { extent }\end{array}$ & $\begin{array}{l}\text { To a very } \\
\text { great extent }\end{array}$ \\
\hline There is adequate electricity & 14.9 & 9.9 & 35.9 & 37.4 & 1.9 & 3.015 \\
\hline $\begin{array}{l}\text { The cost of electricity is affordable } \\
\text { to your sector }\end{array}$ & 17.3 & 9.5 & 35.5 & 36.6 & 1.1 & 2.905 \\
\hline
\end{tabular}

Source: Research Data (2013)

Roads and Performance of SMEs. 59.5\% of the respondents generally reported that to a great extent there were adequate roads to access their businesses while $40.5 \%$ reported to some extent. In addition, study findings revealed that $66.8 \%$ of the respondents generally reported that to a great extent the roads were well maintained while $33.2 \%$ reported to some extent.

Table 15 Effect of Roads on Performance of SMEs

\begin{tabular}{|c|c|c|c|c|c|}
\hline \multirow[t]{2}{*}{ Statement } & \multicolumn{5}{|c|}{ Percentage Response (\%) } \\
\hline & $\begin{array}{l}\text { Not at } \\
\text { all }\end{array}$ & $\begin{array}{l}\text { To a low } \\
\text { Extent }\end{array}$ & $\begin{array}{ll}\text { To } & \text { some } \\
\text { extent }\end{array}$ & $\begin{array}{l}\text { To a greater } \\
\text { extent }\end{array}$ & $\begin{array}{l}\text { To a very great } \\
\text { extent }\end{array}$ \\
\hline $\begin{array}{l}\text { There is adequate roads to access } \\
\text { your business }\end{array}$ & 0.0 & 2.7 & 37.8 & 49.2 & 10.3 \\
\hline The roads were well maintained & 0.0 & 1.1 & 32.1 & 47.3 & 19.5 \\
\hline
\end{tabular}

Source: Research Data (2013)

Level of Profits among SMEs. 36.6\% of the respondents generally reported that to a great extent the net income had increased whereas $63.4 \%$ reported to some extent. $44.6 \%$ of the respondents generally reported that to a great extent the operating cash flow had increased while $55.4 \%$ reported to some extent. In addition, $41.6 \%$ of the respondents generally reported that to a great extent the value of the firm had increased while $58.4 \%$ reported to some extent. Finally, $41.6 \%$ of the respondents generally reported that to a great extent the residual income had increased while $48.1 \%$ reported to some extent.

Table 16 Impact of Profitability on Bank Performance

\begin{tabular}{|l|l|l|l|l|l|}
\hline Statement & \multicolumn{5}{|c|}{ Percentage Response (\%) } \\
\hline & $\begin{array}{l}\text { Not at } \\
\text { all }\end{array}$ & $\begin{array}{l}\text { To a low } \\
\text { Extent }\end{array}$ & $\begin{array}{l}\text { Tome some } \\
\text { extent }\end{array}$ & $\begin{array}{l}\text { To } \\
\text { greater } \\
\text { extent }\end{array}$ & $\begin{array}{l}\text { To a very } \\
\text { great extent }\end{array}$ \\
\hline Net income have increased & 0.0 & 1.2 & 62.2 & 35.1 & 1.5 \\
\hline Operating cash flow have increased & 0.0 & 1.2 & 54.2 & 40.8 & 3.8 \\
\hline Value of the firm have increased & 0.0 & 3.4 & 55.0 & 38.9 & 2.7 \\
\hline Residual income have increased & 0.0 & 4.2 & 43.9 & 49.6 & 2.3 \\
\hline
\end{tabular}

Source: Research Data (2013)

Level of Production Output among SMEs. $51.9 \%$ of the respondents generally reported that to a great extent the level of output had increased whereas $48.1 \%$ reported to some extent. Furthermore, $62.6 \%$ of the respondents generally reported that to a great extent there was no wastage of raw materials whereas $37.4 \%$ reported to some extent. 
Table 17 Level of Production Output

\begin{tabular}{|l|l|l|l|l|l|}
\hline Statement & Not at all & $\begin{array}{l}\text { To a low } \\
\text { Extent }\end{array}$ & $\begin{array}{l}\text { To some } \\
\text { extent }\end{array}$ & $\begin{array}{l}\text { To } \\
\text { greater a } \\
\text { extent }\end{array}$ & $\begin{array}{l}\text { To a very great } \\
\text { extent }\end{array}$ \\
\hline The level of output have increased & 0.0 & 4.2 & 43.9 & 49.2 & 2.7 \\
\hline There was no wastage of raw materials & 0.0 & 3.1 & 34.3 & 56.5 & 6.1 \\
\hline
\end{tabular}

Source: Research Data (2013)

Correlations Matrix. The findings indicate that access to finance was significantly associated with profits ( $\mathrm{r}$ $=0.251, \mathrm{P}<0.05)$ and production output $(\mathrm{r}=0.227, \mathrm{P}<0.05)$. This implies that an increase in access to finance results in an increase in profits and production output of SMEs. Further, study findings reveal that management skills was significantly associated with both profits $(\mathrm{r}=0.226, \mathrm{P}<0.05)$ and production output $(\mathrm{r}=0.215, \mathrm{P}<$ 0.05 ). This implies that an increase in management skills results in an increase in profits and production output of SMEs. Findings also indicate that macro environment was not significantly associated with profits $(r=0.120$, $\mathrm{P}>0.05)$ but significantly associated with production output $(\mathrm{r}=0.220, \mathrm{P}<0.05)$. This implies that an increase in macro environment resulted in an increase in production output but not profits of SMEs in the study area. Finally, correlation results indicate that infrastructure was not found to be significantly associated with both profits $(\mathrm{r}=0.087, \mathrm{P}>0.05)$ and production output $(\mathrm{r}=0.008, \mathrm{P}>0.05)$. This implies that an increase in infrastructure did not result in an increase in profits and production output among SMEs in the study area

Table 18 Correlations Matrix

\begin{tabular}{|c|c|c|c|}
\hline Independent Variables & Statistics & \multicolumn{2}{|c|}{ Dependent Variables } \\
\hline & & Profit & Production \\
\hline \multirow{2}{*}{ Lending terms and conditions } & Correlation Coefficient (r) & $.265^{* *}$ & $.241 * *$ \\
\hline & Significance Level (p-value) & .000 & .000 \\
\hline \multirow[t]{2}{*}{ Collateral requirement } & Correlation Coefficient & $.177^{* *}$ & .118 \\
\hline & Significance Level (p-value) & .004 & .056 \\
\hline \multirow[t]{2}{*}{ Number of years in operation } & Correlation Coefficient & $.144 *$ & $.165^{* *}$ \\
\hline & Significance Level (p-value) & .020 & .008 \\
\hline \multirow[t]{2}{*}{ Combined Access to Finance } & Correlation Coefficient & $.251 * *$ & $.227 * *$ \\
\hline & Significance Level (p-value) & .000 & .000 \\
\hline \multirow[t]{2}{*}{ Financial Management } & Correlation Coefficient & $.335^{* *} *$ & $.271 * *$ \\
\hline & Significance Level (p-value) & .000 & .000 \\
\hline \multirow[t]{2}{*}{ Marketing Management } & Correlation Coefficient & .045 & .071 \\
\hline & Significance Level (p-value) & .473 & .252 \\
\hline \multirow[t]{2}{*}{ Entrepreneurial Skills } & Correlation Coefficient & .098 & .107 \\
\hline & Significance Level (p-value) & .114 & .083 \\
\hline \multirow[t]{2}{*}{ Combined Management Skills } & Correlation Coefficient & $.226 * *$ & $.216 * *$ \\
\hline & Significance Level (p-value) & .000 & .000 \\
\hline \multirow[t]{2}{*}{ Regulatory and Policy Issues } & Correlation Coefficient & $.161 * *$ & $.163 * *$ \\
\hline & Significance Level (p-value) & .009 & .009 \\
\hline \multirow[t]{2}{*}{ Suppliers } & Correlation Coefficient & .115 & .023 \\
\hline & Significance Level (p-value) & .063 & .717 \\
\hline \multirow[t]{2}{*}{ Distributors } & Correlation Coefficient & .074 & $.227 * *$ \\
\hline & Significance Level (p-value) & .230 & .000 \\
\hline \multirow[t]{2}{*}{ Customers } & Correlation Coefficient & .038 & .057 \\
\hline & Significance Level (p-value) & .543 & .354 \\
\hline \multirow[t]{2}{*}{ Competitors } & Correlation Coefficient & .077 & $.127 *$ \\
\hline & Significance Level (p-value) & .214 & .040 \\
\hline \multirow[t]{2}{*}{ Combined Macro Environment } & Correlation Coefficient & .120 & $.220 *$ \\
\hline & Significance Level (p-value) & .051 & .040 \\
\hline \multirow[t]{2}{*}{ Water } & Correlation Coefficient & $.207 * *$ & $.126^{*}$ \\
\hline & Significance Level (p-value) & .001 & .002 \\
\hline \multirow[t]{2}{*}{ Electricity } & Correlation Coefficient & .045 & $.147 *$ \\
\hline & Significance Level (p-value) & .473 & .017 \\
\hline \multirow[t]{2}{*}{ Roads } & Correlation Coefficient & .080 & $.124 *$ \\
\hline & Significance Level (p-value) & .055 & .045 \\
\hline \multirow[t]{2}{*}{ Combined Infrastructure } & Correlation Coefficient & .087 & .008 \\
\hline & Significance Level (p-value) & .674 & .895 \\
\hline
\end{tabular}


** Correlation is significant at the 0.01 level (2-tailed).

*Correlation is significant at the 0.05 level (2-tailed) Sources: Research data, 2013

In order to determine the effect of factors on performance of SMEs and test the study hypotheses, the combined independent variables (access to finance, management skills, macro environment and infrastructure) were regressed on the dependent variable (performance of SMEs).

Table 19 Regression Analysis

\begin{tabular}{|c|c|c|c|c|c|c|}
\hline \multicolumn{2}{|c|}{ Model } & \multicolumn{2}{|c|}{ Unstandardized Coefficients } & \multirow{2}{*}{$\begin{array}{c}\begin{array}{c}\text { Standardized } \\
\text { Coefficients }\end{array} \\
\text { Beta }\end{array}$} & \multirow[t]{2}{*}{$\mathbf{t}$} & \multirow[t]{2}{*}{ Sig. (P-value) } \\
\hline & & B & Std. Error & & & \\
\hline \multirow[t]{5}{*}{1} & (Constant) & 15.518 & 1.697 & & 9.142 & .000 \\
\hline & combined Financial access & .161 & .039 & .236 & 4.168 & .000 \\
\hline & Combined Management skills & .208 & .034 & .365 & 6.039 & .000 \\
\hline & Combined Macro environment & -.150 & .029 & -.323 & -5.180 & .000 \\
\hline & Combined Infrastructure & .060 & .046 & .076 & 1.300 & .195 \\
\hline
\end{tabular}

Source: Research data, 2013

Results of regression analysis (Table 19) reveal that access to finances was found to significantly affect performance of SMEs $(\mathrm{P}=0.000, \mathrm{P}<0.05)$. Hence the null hypothesis that Accesses to finance (Lending terms, Collateral requirements and number of years in operation) does not significantly affect performance of SMEs in Jua Kali sector was rejected.

Findings also indicate that combined management skills was found to significantly affect performance of SMEs $(\mathrm{P}=0.000, \mathrm{P}<0.05)$. Thus the null hypothesis that Management skills (Financial, Marketing and Entrepreneurial skills) do not significantly affect performance of SMEs in Jua Kali sector was rejected. In addition, findings reveal that combined macro environment was found to significantly affect performance of SMEs $(\mathrm{P}=0.000, \mathrm{P}<0.05)$. Thus the null hypothesis that Macro-environment factors (Regulation and policy issues, suppliers, distributors, customers and competitors) do not significantly affect performance of SMEs in Jua Kali sector was rejected. Finally, findings indicate that Infrastructure was not found to significantly affect performance of SMEs $(\mathrm{P}=0.195, \mathrm{P}>0.05)$. Thus the null hypothesis that Infrastructure (Water, Roads and Electricity) does not significantly affect performance of SMEs in Jua Kali sector was accepted.

The regression summary model (Table 20), indicates that the co-efficient of determination (R) with a value of 0.595 and $\mathrm{R}^{2}=0.355$ or $35.5 \%$. These findings confirm that the observed change in performance attributed to the identified factors was $35.5 \%$ while the remaining percentage could be explained by other intervening factors.

Table 4.20 Model Summary

\begin{tabular}{|c|c|c|c|c|c|c|c|c|c|}
\hline \multirow[b]{2}{*}{ Model } & \multirow[b]{2}{*}{$\mathrm{R}$} & \multirow[b]{2}{*}{ R Square } & \multirow[b]{2}{*}{$\begin{array}{l}\text { Adjusted R } \\
\text { Square }\end{array}$} & \multirow[b]{2}{*}{$\begin{array}{c}\text { Std. Error of the } \\
\text { Estimate }\end{array}$} & \multicolumn{5}{|c|}{ Change Statistics } \\
\hline & & & & & $\begin{array}{l}\text { R Square } \\
\text { Change }\end{array}$ & F Change & df1 & df2 & Sig. F Change \\
\hline 1 & $.595^{\mathrm{a}}$ & .355 & .318 & 2.20165 & .355 & 9.692 & 14 & 247 & .000 \\
\hline
\end{tabular}

a. Predictors: (Constant), Roads, Distributors, Customers, Financial management, Lending terms and conditions, Entrepreneurial skills, Electricity, Competitors, Duration of business, Regulation and policy issues, Marketing management, Suppliers, Collateral requirements, Water.

\section{Concluding Remarks}

The broad objective of this study was to evaluate the factors affecting the performance of SMEs in the Jua Kali sector in Nakuru Town. The study specifically sought to address the effect of the identified factors on the performance of SMEs in Jua Kali sector.

The overall conclusion is that SMEs access to finance had the potential to positively influence performance of SMEs in Jua Kali Sector, however access to finance were yet to be fully utilized to the advantage of the SMEs in the study area. Management skills had the potential to positively and significantly affect performance of SMEs and yet had only been marginally adopted by the SMEs in the study area. Similarly, the study concluded that the effect of macro environment on performance of SMEs was positive and significant especially on production output despite being moderately rated among the SMEs. Finally, the study concluded that infrastructure was not statistically found to significantly affect performance of SMEs in the study area. 
The study findings revealed that although the access to finance had the capability to positively influence performance of SMEs they had not been fully utilized to the advantage of the SMEs in the Jua Kali Sector. Therefore, the banks should improve on the Lending terms and conditions to the advantage of SMEs, Collateral requirements and Number of years in order to increase performance. From the study findings it was evident that management skill had the potential to positively and significantly affect performance of SMEs and yet had only been marginally adopted by the SMEs. Accordingly, SME businesses should focus on acquiring appropriate management skills such as financial, marketing and entrepreneurial skills.

The effect of macro environment on performance of SMEs was positive and significant especially on production output despite being moderately rated among the SMEs. This study concludes that the SME businesses should effectively strengthen the macro environment in order to increase their performance.

Finally, the study concluded that infrastructure was not statistically found to significantly affect performance of SMEs in the study area. This study recommends that the SME businesses should effectively address the infrastructure especially in terms of electricity and roads in order to increase their performance

This study provided relevant insight on the factors affecting the performance of SMEs in the Jua Kali Sector. It is important that further research is carried out to assess the impact of the factors on performance of other SMEs outside the Jua Kali Sector. The same research should be conducted in the same areas but more focus should be on qualitative measures of performance.

\section{References}

[1.] Amyx,C.(2005). Small Business challenges- The perception problem: Size Doesn't matter. Washington Business Journal 2,4-16.

[2.] Aryeetey, E., A. Baah-Nuakoh, T. Duggleby, H. Hettige, and W. F. Steel, (1994). "Supply and Demand for Finance of Small Scale Enterprises in Ghana”, Discussion Paper No. 251, World Bank, Washington, DC.

[3.] Biekpe, N. (2004), 'Financing Small Business in Sub-Saharan Africa: Review of Some Key Credit Lending Models and Impact of Venture Capital', Journal of African Business, 5(1), 342-378.

[4.] Bigsten, A., et al, (2000), "Credit Constraints in Manufacturing Enterprises in Africa", Working Paper WPS/2000. Centre for the study of African Economies, Oxford University, Oxford

[5.] Buatsi, S.N. (2002), 'Financing Non-traditional Exporters in Ghana', The Journal of Business and Industrial Marketing, $17(6), 56$.

[6.] Carter, Brush, Greene, Gatewood, \& Hart, (2003). Women entrepreneurs who break through to equity financing; the influence of human, social and financial capital. venture capital. An International and Financial Journal of Entrepreneurial Finance 5(1), 67.

[7.] CBS, K-Rep, and ICEG (1999). National MSE Baseline Survey

[8.] CBS-GoK (2006), Economic Survey, Report by Task Force on Micro and Small Scale Enterprises:Nairobi. Ministry of Labour and Human Resource Development, Nairobi.

[9.] CBS-GoK (2012), Economic survey, Ministry for Planning and National Development, Nairobi

[10.] GoK (Government of Kenya). (2007). Kenya Vision 2030: A Globally Competitive and Prosperous Kenya. October 2007. Nairobi: Government Printer.

[11.] Ibrahim A and J.Goodwin. (1986). Perceived causes of success in small business. American Journal of Small Business, 11, (Fall).

[12.] International Labour Organization (1972), "Employment, Incomes and Equity: A Strategy for Increasing Productive Employment in Kenya"(Geneva: ILO).

[13.] Kapoor, D. et al.(1997) The World Bank: Its First Half Century (Washington: The Brookings Insitution)

[14.] Kenneth K. (1996), Jua Kali Kenya: Change and Development in an Informal Economy, 1970- 95 (London: James Curry, 1996) 25.

[15.] Lader, P. (1996), "The Public/Private Partnership", Springs Spring, 35(2).

[16.] Levy B (1993) 'Obstacles to Developing Indigenous Small and Medium Enterprises: An Empirical Assessment', The World Bank Economic Review 7 (1), 65-83

[17.] Levy B (1993) 'Obstacles to Developing Indigenous Small and Medium Enterprises: An Empirical Assessment', The World Bank Economic Review 7 (1), 65-83

[18.] Lichtenstein B.M.B and C.G Brush. (2001). How do resource bundles develop and change in model and longitudinal exploration. Entrepreneurship theory and practice 25(3): 35-58

[19.] Liedholm C, MacPherson M and Chuta E (1994) 'Small Enterprise Employment Growth in new ventures? A dynamic Journal of Agricultural Economics, Vol. 76, 10-15.

[20.] Liedholm, Can and D. Mead, (1999). Small Enterprises and Economic Development: The Dynamic Role of Micro and Small Enterprises. London; Routledge.

[21.] Lussier, R. N. (1996). Reasons why small businesses fail: and how to avoid failure. The Entrepreneur Executive, 1(2).

[22.] Maundu J. N. (1992). Process and Product in Science and Technology Learning in Kenya Schools: A study of Selection and Classification skills in Jua Kali and Primary School settings. Unpublished IDRC - sponsored Research Report.

[23.] Mead D.C \& Liedholm (1998), 'The Dynamics of Micro and Small Enterprises in Developing World Development Vol. 26 No. 1

[24.] Mugwara, D. (2000). Small and medium enterprise policy \& strategy: Ministry of Industry \& Commerce

[25.] Murphy, K. M., A. Shleifer, and R. W. Vishny (1996): The allocation of talent: Implications for growth. The Quarterly Journal of Economics, 106(2).

[26.] National Baseline Survey. (1993, 1995). National Micro and Small Enterprise Baseline Survey. Nairobi: GEMINI Studies.

[27.] National Baseline Survey. (1993, 1995). National Micro and Small Enterprise Baseline Survey. Nairobi: GEMINI Studies

[28.] Ombura, C.O. (1997). Towards an environmental planning approach in urban industrial siting and operations in Kenya: The case of Eldoret Town. Ph.D Dissertation, Netherlands Geographical society/ Department of Human Geography|, Faculty of Environmental Sciences University of Amsterdam. 
[29.] Ouma S., J. Njeru, A. Kamau, D. Khainga and B. Kiriga (2007), Estimating the size of the underground economy in Kenya, KIPPRA Discussion Paper, No. 82, Nairobi: Kenya Institute for Public Policy Research and Analysis

[30.] Parker, R., R. Riopelle, and W. Steel, (1995). "Small Enterprises Adjusting to Liberalisation in Five African Countries", World Bank Discussion Paper, No 271, African Technical Department Series, The World Bank, Washington DC.

[31.] Peel M and Wilson N (1996) 'Working Capital and Financial Management Practices in the Small Form Sector', International Small Business Journal, Vol. 14, 67-69

[32.] Republic of Kenya (2005). Sessional Paper No. 2 of 2005 on small Enterprise and Jua Kali Development in Kenya, Nairobi, Government Printer

[33.] Rozee, L. (2003). Working Papers on Spatial Planning (ODPM)

[34.] Saito K and Villanueva D (1981) 'Transactions costs of credit to the small-scale sector in the Philippines', Economic Development and Cultural Change, (29), 3

[35.] Schlogl, H. (2004). Small and medium enterprises: Seizing the potential. Organizational for Economic Cooperation and Development, No. 243, pp. 46-48.

[36.] Sowa, N. K., A. Baah-Nuakoh, K. A. Tutu, and B. Osei, (1992). "Small Enterprise and Adjustment, The Impact of Ghana's Economic Recovery Programme on Small-Scale Industrial Enterprises", Research Reports, Overseas Development Institute, $111 \quad$ Westminster Bridge Road, London SE1 7JD

[37.] Tewdwr, Mark-Jones. (2004). Spatial Planning: Principles and Culture. Journal of Planning and Environment Law. May 2004

[38.] Tushabonwe-Kazooba, C. (2006). Causes of Small Business Failure in Uganda: A Case Study from Bushenyi and Mbarara Towns. African Studies Quarterly, 8(4) Retrieved from http// web.Africa.ufl.edu]asq/v8/v8i4a3.htm.

[39.] Van De Ven, H. (1993). The development of an infrastructure for entrepreneurship. Journal of Business Venturing 8, 211230.

[40.] Van Stel, A. J., and D. J. Storey (2004): The link between firm births and job creation: Is there a up as tree effect? Regional Studies, 38(8), 893-909.

[41.] Yamane, Taro.(1967). Statistics: An Introductory Analysis, 2nd Ed., New York: Harper and

[42.] Yonggui,W., Yuli, Z., and Hing-PLO. (2002).The key factors distinguishing high-growth small $\quad$ and medium-sized enterprises from those of poor performance: Evidence from China. Retrieved http://www.ncer.cn/lunwen/paper2/wp200212.pdf

Appendix I:

Summary of SMEs in Nakuru Municipality As At January 2013

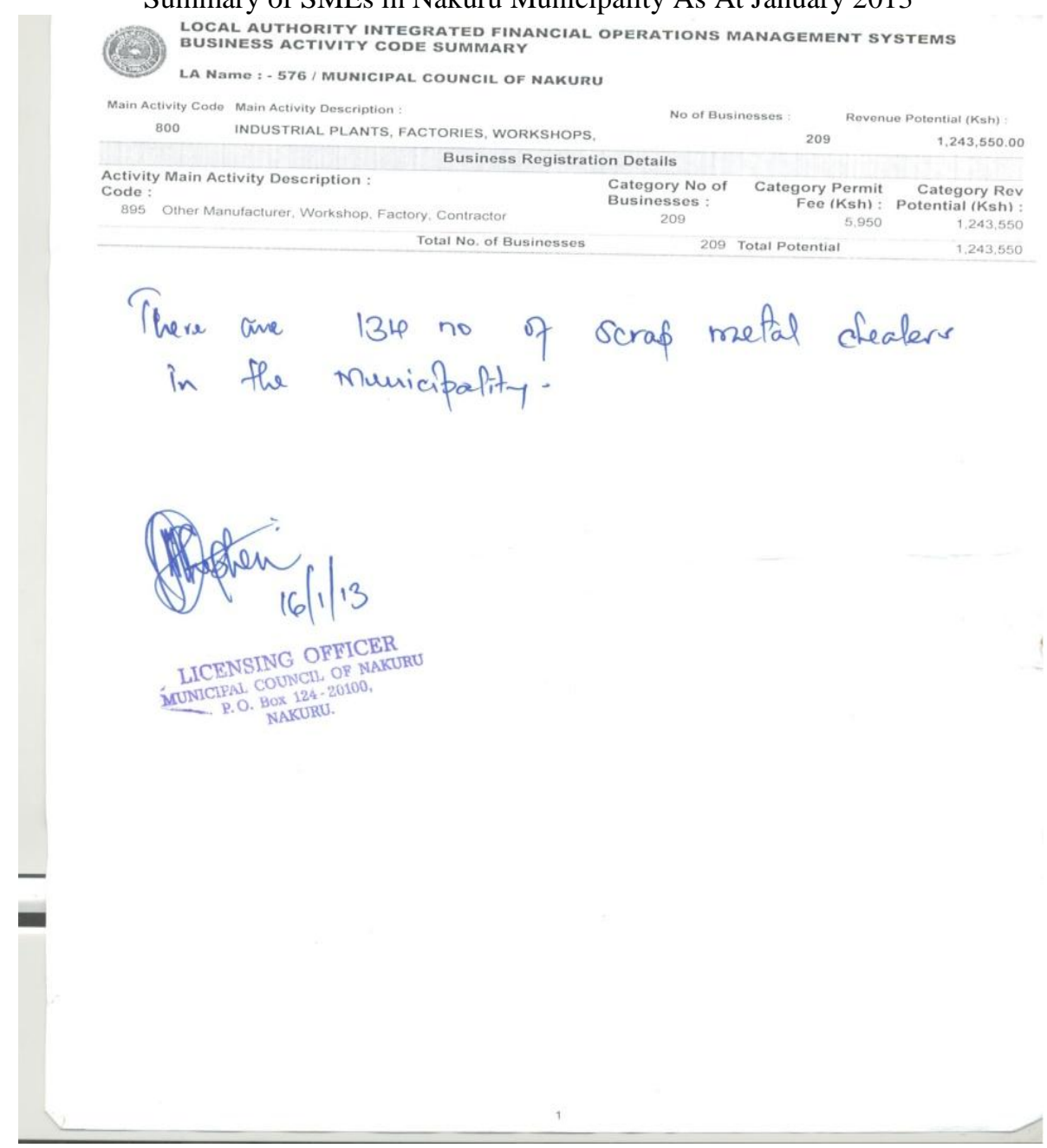




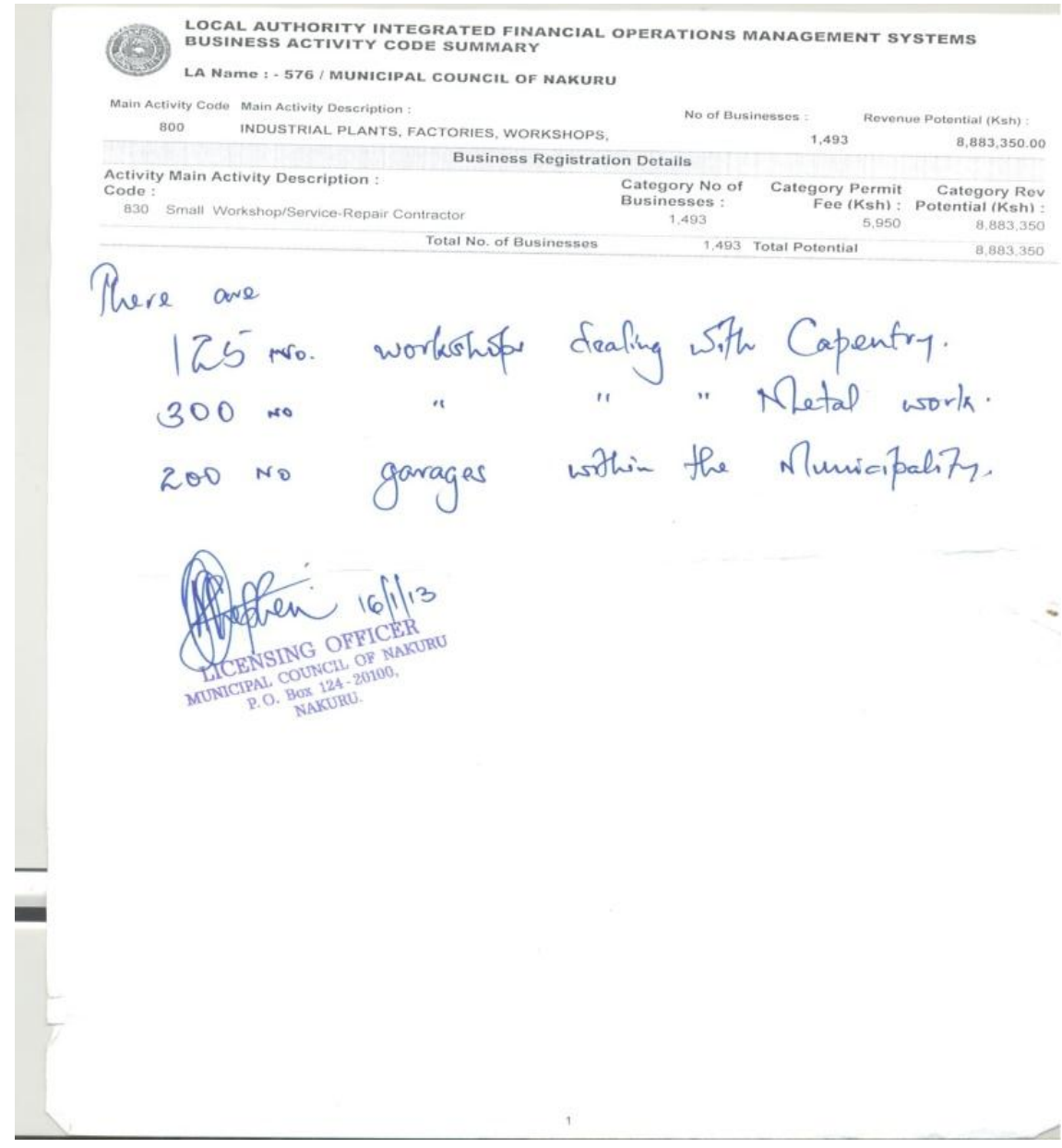

